\title{
Athletic Ticket Pricing in the Collegiate Environment: An Agenda for Research
}

\author{
Craig A. Morehead \\ Coastal Carolina University \\ Stephen L. Shapiro \\ Old Dominion University \\ Timothy M. Madden \\ East Carolina University \\ Lamar Reams \\ Old Dominion University \\ Chad D. McEvoy \\ Northern Illinois University
}

\begin{abstract}
As pressure mounts for intercollegiate athletic departments to be more selfsufficient, administrators must respond by increasing generated revenues. Despite the importance of ticket sales in this endeavor, however, little is known about the underlying ticket pricing structures and policies used by National Collegiate Athletic Association (NCAA) institutions. Of the limited existing scholarship focused on managerial pricing decisions in the field of sport management, only professional sports settings have been addressed. Given the unique operational differences between professional and intercollegiate sport, this paper is designed to establish a foundation from which to build future research concerning the pricing of college sport tickets. The frameworks of stakeholder theory and institutional theory are proposed to ground future study in an attempt to strengthen our understanding of the process and behavior of price setting in intercollegiate athletics.
\end{abstract}

Keywords: revenue generation, marketing, stakeholder theory, institutional theory, athletic administration, NCAA

\footnotetext{
Morehead is with the Department of Recreation and Sport Management, Coastal Carolina University, Conway, SC. Shapiro and Reams are with the Dept. of Human Movement Sciences, Old Dominion University, Norfolk, VA. Madden is with the Dept. of Management, East Carolina University, Greenville, NC. McEvoy is with the Dept. of Kinesiology and Physical Education, Northern Illinois University, DeKalb, IL. Address author correspondence to Craig Morehead at cmorehead@coastal.edu.
} 
In the current financial landscape of higher education that is increasingly focused on the bottom line (see Schrecker, 2010), institutional administrators are leaning on units across campus to seek, secure, and sustain external funding, which has led to greater emphasis on faculty grant writing and development office fundraising (Weisbrod, Ballou, \& Asch, 2008). Meanwhile, as "auxiliary" units, intercollegiate athletic departments are increasingly required to be self-sufficient (Kretovics, 2011). Coupled with calls to reduce or eliminate athletics subsidies (i.e., Ridpath et al., 2015), longstanding concerns over how sports serve the institutional mission (Clotfelter, 2011) make it all the more important for athletic administrators to consider all external revenue sources at their disposal in an effort to remain financially solvent.

Fulks (2015) refers to such external sources as generated revenues, which are defined as "revenue sources that are not dependent upon institutional entities outside the athletics department" (p. 9), and includes ticket sales, broadcast receipts, donations, game guarantees, royalties, and league distributions. During the 2014 fiscal year, ticket sales were the second-largest source of generated revenue among National Collegiate Athletic Association (NCAA) Football Bowl Subdivision (FBS) institutions, accounting for $25 \%$ of revenues, coming in just behind contributions (26\%), and just ahead of distributions (24\%; Fulks, 2015). However, this revenue breakdown does not account for the close relationship between ticket sales and donations, as many athletic departments require minimum contributions to secure the rights to purchase season tickets for sports such as football and men's basketball (Mahony, Gladden, \& Funk, 2003).

Despite the importance of generated revenues derived from ticket sales, however, we know very little of the underlying ticket pricing structures used by NCAA institutions. In fact, Kirby (2014) suggests that credible pricing for college sports was largely ignored until the financial crisis circa 2007. With that in mind, formalized price structuring among intercollegiate athletic departments is fledgling, which may help explain the lack of scholarship in this area. To better understand how prices are determined, it is important to know who might sway pricing decisions within college athletics through the lens of stakeholder theory (Freeman, 1984), and what pressures exist that might influence pricing processes through the lens of institutional theory (DiMaggio \& Powell, 1983). These are unique considerations in intercollegiate athletics based on the number of sponsoring institutions, the wide variety of sports sponsored by those institutions, and the multiple levels of governance from which departments must operate.

Although the financial needs of individual athletic departments may vary, ticket sales play a significant role in generated revenue across NCAA Division I (Fulks, 2015). Therefore, the primary market pricing of game tickets is an important first step that warrants further investigation, especially considering indications of pricing inefficiencies in college football (Sanford \& Scott, 2014), and dwindling attendance in both football (Smith, 2015a) and men's basketball (Smith, 2015b). Efficient pricing strategies are paramount for sport organizations, as poor policies may leave seats unutilized if tickets are priced too high and lost revenues if priced too low, while more efficient strategies have the potential to boost revenues in both low and high demand situations (Shapiro \& Drayer, 2012). Despite this need for efficiency, however, Rascher and Schwarz (2010) suggest that sports teams typically achieve optimal pricing through trial and error. 
Although pricing is the only marketing mix element with the direct potential to produce revenue (Kotler, 1991), research in this area is scarce, with scholars suggesting it has been neglected (Drayer \& Rascher, 2013). This gap has been addressed in recent years with published pricing research, including a special issue of Sport Marketing Quarterly dedicated to the subject in 2013. However, these studies have been almost singularly focused on professional sport.

Its presence as a multibillion-dollar industry notwithstanding, college sport has been largely ignored in the ticket pricing literature. More specifically, although anecdotal evidence exists of price discrimination practices at work throughout college sport, there are no known investigations of how NCAA athletic administrators have arrived at such pricing decisions. Therefore, the purpose of this paper is to establish a foundation from which to build future research concerning ticket pricing in the unique environment of intercollegiate athletics. To begin addressing the dearth of literature on the subject, we will first present an overview of stakeholder theory and institutional theory and how each has been used in research of intercollegiate athletics. Then, we present rationale for the independent study of pricing for the college spectator sport market. Next, we provide a review of existing sport pricing literature to frame the current body of knowledge on the subject, and provide a series of propositions to suggest potential avenues for future research focused on college sport ticket pricing. Finally, we conclude with a reflection on the unique nature of intercollegiate athletics and the ways in which our understanding of the college sport ticket pricing phenomenon can be extended using the frameworks of stakeholder theory and institutional theory.

\section{Theoretical Frameworks}

In an attempt to help fill a void in the sport marketing literature concerning managerial pricing policy, two organizational theories can be used to broaden the literature base of price-setting behavior in intercollegiate athletics — stakeholder theory and institutional theory.

\section{Stakeholder Theory}

In his seminal work on stakeholder management, Freeman (1984) defines a stakeholder as "any group or individual who can affect or is affected by the achievement of the organization's objectives" (p. 46). This is a key point of understanding for any organization, including sport organizations, as each component of a firm's operation is influenced in some capacity by its stakeholders, especially because they fund, design, build, operate, maintain, and dispose of the systems for which they belong (Hester, Bradley, \& Adams, 2012).

Mitchell, Agle, and Wood (1997) make an important contribution to the idea of stakeholder identification, as they formulated a typology that categorizes individuals into attributes of power, legitimacy, and urgency. A powerful stakeholder is one who has an influential effect on others. Stakeholder legitimacy is defined as "a generalized perception or assumption that the actions of an entity are desirable, proper, or appropriate within some socially constructed system of norms, values, beliefs, definitions" (Mitchell et al., 1997, p. 869). Finally, urgency is "the degree to which stakeholder claims call for immediate attention” (Mitchell et al., 1997, p. 
869). From these three overarching typologies, Mitchell et al. (1997) then categorize individuals even further, with anyone exhibiting only one of these three factors considered a latent stakeholder with few expectations. Expectant stakeholders are those exhibiting any two of the attributes, which requires organizational response. Finally, definitive stakeholders are those who hold power, legitimacy, and urgency, and thus take priority for the organization.

Organizations require input from numerous stakeholders to achieve their stated objectives. Internal stakeholders are those who have a direct relationship with managers, while external stakeholders have no such interaction. Also described as supply-side stakeholders, internal stakeholders are workers, managers, suppliers, and financiers who assist in the production and distribution of a product; while external stakeholders are considered demand-side stakeholders, describing those who consume such as clients, customers, donors, or sponsors (Ben-Ner \& Gui, 1993). Considering the vast number of individuals who have a stake in intercollegiate athletics, these types of categorizations can be quite useful. Therefore, stakeholder identification can be a pragmatic exercise for administrators, as "understanding and dealing with identifiable stakeholders ... offers clear strategic and efficiency advantages over conceiving of an organization's environment as being composed of innumerable individuals and institutions" (Putler \& Wolfe, 1999, p. 322).

Although categorization is a crucial first step, managers must also be concerned with the characteristics and motivations of each stakeholder group as "their values, their relative influence on decisions and the nature of the situation are all relevant information" (Jones \& Wicks, 1999, p. 208). Developing relationships, taking an interest in stakeholder needs, and understanding their desires are paramount to long-term viability. In one of the earliest works of managerial goal-setting in college athletics, Chelladurai and Danylchuk (1984) state that "although the actual goals pursued by an organization are largely set by the key decision-makers, such goals must, in the long run, reflect the desires of several constituencies of the organization" (p. 39).

Putler and Wolfe (1999) are among the scholars who have applied stakeholder theory within the context of intercollegiate athletics, using conjoint analysis to investigate the perceptions of success from several stakeholder groups. Among their findings, Putler and Wolfe (1999, p. 315) concede that "addressing the priorities of stakeholder groups ... might not be a simple matter," which alludes to the complexity of the decision-making processes faced by athletics administrators. In addition, Covell has applied stakeholder theory to ice hockey (2004) and football (2005) season-ticket holders at an Ivy League school, suggesting that those with strong attachment and allegiance impact athletic policy. Specifically, Covell (2004) identifies intercollegiate athletics as "a stakeholder-oriented system, where schools use athletics to foster a sense of community with students, alumni, and the general public" (p. 15).

\section{Institutional Theory}

In their seminal work on institutional theory, DiMaggio and Powell (1983) describe an organizational propensity for homogenization called isomorphism, which "is a constraining process that forces one unit in a population to resemble other units that face the same set of environmental conditions" (p. 149). At the heart of 
institutionalization is the idea that organizational survival depends on conforming to prevailing environmental rules and cultures, thereby achieving legitimacy when adhering to such norms (DiMaggio \& Powell, 1983). According to Ward (2015), "legitimacy seeking may be especially important for organizations that depend on stronger organizations for resources, function in environments with ambiguous or disputed goals, and rely on managers and staff with similar academic training" (p. 19).

DiMaggio and Powell (1983) identified three forms of isomorphism - coercive, mimetic, and normative. Coercive isomorphism reflects both formal pressures of political influence and informal pressures of cultural expectations. In the realm of intercollegiate athletics, the NCAA is a political structure that forces resemblance, although conference membership may also exert both formal and informal pressures on an institution. Mimetic isomorphism describes situations in which organizations imitate the actions of peers that have achieved levels of success and stature, especially during times of uncertainty or when faced with ambiguous goals. Some suggest there may be a general lack of entrepreneurship among athletic administrators (i.e., Ward, 2015), who might instead opt to reincarnate policies, programs, or promotions that have proven successful at other institutions. This may be by design, however, as imitation could be seen as a strategy to ameliorate the effects of insufficient resources (O'Hallarn, Morehead, \& Pribesh, 2016). Finally, normative isomorphism stems from socialization via professional, educational, or networking connections. Such training is common in the NCAA (Smith \& Washington, 2014), as many athletic administrators receive formal education in the field of sport management and belong to the same professional organizations.

Several studies of intercollegiate athletics have been grounded in institutional theory. In a study of managerial activities among Canadian intercollegiate athletic administrators, Danylchuk and Chelladurai (1999), found isomorphic tendencies through response similarities on 19 variables, irrespective of school size, sports sponsored, or time served. Cunningham and Ashley (2001) investigated isomorphism in the NCAA through the incorporation of population ecology, institutionalism, and strategic choice, with the latter garnering the most support. Cunningham (2009) again used institutional theory to examine diversity-related change processes in intercollegiate athletic administration, finding that change was influenced by political, functional, and social pressures. Kelly and Dixon (2011) used resource-based and institutional theories to investigate the strategies used by institutions adding football, finding that the sport helps create a sense of community and enhances institutional value. More recently, Ward (2015) conducted a content analysis of NCAA Division I athletic mission statements, finding that despite their communicative capability, differences in stated missions between more and less accomplished programs could not be detected.

Although stakeholder theory and institutional theory can be used separately as frameworks for studying ticket pricing in intercollegiate sport, there is also justification and precedence for using these theories in concert, as was done by Welty Peachey and Bruening (2011) in their investigation of organizational change within a Football Championship Subdivision (FCS) athletic department. Specifically, they found coercive pressures stemming from conference affiliation, economic conditions, and stakeholder groups such as alumni, parents, and fans. They also found that stakeholders were sensitive to organizational history and tradition, and institutional 
support and politics, in addition to being concerned about organizational legitimacy, which can lead to mimetic behavior. Furthermore, Welty Peachey and Bruening (2011) advocate for additional research to better understand the forces that influence organizational change and decision-making in sport settings, especially in regards to how such decisions are affected by myriad stakeholders with varying interests.

\section{Professional vs. College Sport}

Noticeably absent from sport-based pricing literature are studies focused on the policies and processes of collegiate decision makers. To date, the majority of pricing studies have focused on professional spectator sport markets. However, as Pappano and Tracy (2009) suggest, "the literature on athletic and ticket pricing struggles with the lack of distinction between college and professional teams" (p. 3). Although professional and college sport may share operational similarities, such as a reliance on ticket sales as a key revenue stream, the two segments should not necessarily be lumped together into a single grouping of spectator sport.

Sack (1987) suggests that intercollegiate athletic departments are increasingly business- and profit-oriented, therefore modeling professional sport behavior. It is important to note, however, that as auxiliary units under the umbrella of the larger institution, athletic departments are in fact nonprofit — albeit highly-commercialized - organizational divisions (McEvoy, Morse, \& Shapiro, 2013; Pappano \& Tracy, 2009). Given the rules that govern nonprofits, true profit-maximizing behavior among athletic administrators might be considered illegal and puts the entire institution at risk for losing its nonprofit status (Eschenfelder \& Li, 2007).

The existence of such dissonance due to athletic departments modeling profit-seeking behavior despite their nonprofit status was explained by McEvoy et al. (2013) through Bowen's (1980) Revenue Theory of Cost, which states that nonprofit organizations will avoid significant surpluses by spending money that equals (or sometimes outpaces) increases in revenue. Therefore, although athletic departments may have an objective to increase revenue, there is likely a secondary (perhaps silent) objective to spend the funds raised (Bowen, 1980). As an alternative to the inelastic pricing strategy used by professional teams, the Revenue Theory of Cost may explain under-pricing of game tickets in the primary collegiate market.

Another significant difference between professional and college sport exists in the season-ticket purchase process. In professional sport, a one-time personal seat license fee typically grants the rights-holder long-term access to season tickets so long as such purchases continue uninterrupted. In college sport (specifically football and men's basketball), however, annual donations are often tied to season-ticket purchase rights in a form of second-degree price discrimination known as a twopart tariff (Rascher \& Schwarz, 2010), thus requiring individuals or corporations to make a minimum "gift" to the athletic foundation each year before being granted the opportunity to purchase season tickets (Mahony et al., 2003).

There also exists a significant difference in post season play, where professional sport relies on home venues (Super Bowl notwithstanding), and intercollegiate athletics often utilizes neutral-sites for both league and NCAA postseason tournaments. In addition, in professional sport leagues such as the National Football League (NFL), National Basketball Association (NBA), and National Hockey League (NHL), seating capacities are quite similar. Stark differences exist, however, in the 
seating capacities of college sport venues. For example, within the FBS alone, Charlotte's Jerry Richardson Stadium has a capacity of 15,314 (Charlotte, 2015), while the aptly nick-named "Big House" at Michigan seats 107,601 (Michigan, 2015).

Perhaps the biggest difference between professional and college sport is in organizational structure. In North American professional sport there exists leaguedriven governance structures, whereby the NFL, NBA, NHL, or Major League Baseball (MLB) hold singular sway over individual teams (Hums \& MacLean, 2013). The structure is much more complex in intercollegiate athletics, however. At a microlevel, the athletic department exists as a unit within the larger umbrella of the institution and thus must adhere to rules and operating procedures at the local level. Moving to a meso-level, athletic departments must also follow the bylaws of the athletic conference(s) for which they are affiliated (e.g., Big Ten, Ivy League, Big Sky). Then, from a macro perspective, athletic departments must also operate within the parameters set forth by the NCAA.

Also notably important, the culture of intercollegiate athletics is uniquely different thanks to its students, mascots, pep and marching bands, fight songs, cheers, and traditions. From an anecdotal perspective, the actions of former Michigan Athletic Director Dave Brandon provide a cautionary tale of what can happen when a college athletic department strays from cultural norms in lieu of a more profit-seeking approach. Under his leadership, Michigan athletics broke from tradition, instituted damagingly unpopular business-oriented practices (including dynamic ticket pricing), and ultimately lost the trust of its core constituents - students, alumni, and fans; all of which led to a grassroots uprising to call for his job. Describing the fallout from breaking time-honored traditions at Michigan, Bacon (2015) writes: "After more than a century of sound stewardship, Michigan lost its way. It ignored established safeguards, and forgot the values that had made it great. The resulting downfall was swift and stunning" (p. 460).

In short, it should not be assumed that factors relating to professional sport (or traditional business) will also be true in the collegiate environment. This might be especially true with regard to ticket pricing, as it has been suggested that revenue generation should not necessarily be considered the sole purpose behind intercollegiate athletic programs, as they also act as entertainment platforms, educational experiences, bridges for alumni and their alma mater, and marketing tools for the university (Humphreys, 2006; Matheson, O’Connor, \& Herberger, 2012). Despite their surface-level similarities, it is rational to study professional and college spectator sport as separate entities.

\section{Pricing Literature in Sport}

Despite our position that college and professional sport should be considered separately, the fact remains that the majority of investigations into sport pricing have taken place on the professional level. Therefore, it is important to recognize the extant professional sport pricing literature to use it as both a point of departure and a point of comparison for future studies of intercollegiate sport ticket pricing research. This section provides an overview of the current status of pricing literature in sport management, and offers propositions for how researchers might focus their efforts on pricing in intercollegiate athletics. 


\section{Value}

Although product, place, and promotion are all components of the marketing mix that act to create potential value for the consumer, the element of pricing is how an organization capitalizes and translates that value into revenue. However, the concept of price also includes nonmonetary elements that represent valuation and are important to the purchase decision, such as opportunity costs (Kim \& Trail, 2010), psychological costs, and effort costs (Brayley \& McLean, 2001). The concepts of monetary price and nonmonetary costs are both considered when an individual determines his/her perceived value of a product or service.

Drayer and Shapiro (2011) argue that managers need to understand the factors influencing consumers' valuation of game tickets. However, valuation from a consumer perspective — referred to as willingness to pay (WTP) - is quite different from the valuation placed on a product or service by the seller - referred to as willingness to accept compensation (WTA). The findings from Drayer and Shapiro (2011) on values placed on NBA game tickets are consistent with studies in other markets, which indicate that WTA is valued higher than WTP, a concept known as the endowment effect. As described by Huck, Kirchsteiger, and Oechssler (2005), "the endowment effect describes the fact that people demand much more to give up an object than they are willing to spend to acquire it" (p. 689). On the other end of the value continuum, the concept of consumer surplus describes instances in which the purchaser values an item higher than the price paid, indicating an under-valuation of the commodity on behalf of the seller (Drayer, Rascher, \& McEvoy, 2012). From a managerial perspective, understanding these discrepancies is key when making ticket-pricing decisions, as suboptimal pricing policies can have damaging effects on game attendance and revenue (Drayer \& Shapiro, 2011).

The concept of value is ripe for investigation in intercollegiate athletics using the undergirding of stakeholder theory given the potentially disparate opinions of both demand-side and supply-side stakeholders. Value propositions need to be considered in the unique environment of intercollegiate athletics from the demandside due in part to the donation-based context of season ticket sales (Mahony et al., 2003), and from the supply-side due in part to athletic departments' nonprofit status (McEvoy et al., 2013). Therefore, we propose the following:

Proposition 1: Based on the tenets of stakeholder theory, the consumer(s) (ticket-purchasing fan) and the seller(s) (athletic department) will have differing value perceptions as it relates to price.

\section{Managerial Pricing Strategy}

A rich understanding of the managerial decision-making process cannot be had without conducting research specifically sampling those administrators with direct pricing influence and/or authority. However, in 2001 Reese and Mittelstaedt suggested that, "information regarding the decision-making process in the discipline of ticket management is noticeably absent from the literature" (p. 223). Save a handful of articles, this is still very much the case.

In the first study of managerial ticket-pricing decisions in the sport management literature, NFL ticketing managers were surveyed, and findings indicated that team 
performance, revenue needs, public relations, market toleration, fan identification, average league price, and economic factors were of moderately high importance in influencing pricing decisions (Reese \& Mittelstaedt, 2001). One flaw in the research design identified by the authors was an assumption that ticket managers were pricing decision-makers for their organizations, when in actuality several indicated that such decisions were made at higher administrative levels.

This warning should be heeded in future research focused on decision-making, and provides ample justification for applying stakeholder theory to ticket pricing research in an effort to more deeply understand the subject from multiple internal, supply-side perspectives. A crucial element in such investigations is the identification of those internal stakeholders that are (or should be) part of the decisionmaking process. In the case of intercollegiate athletic pricing decisions, we suggest several individuals who should be involved in the process. As departmental leader, athletic directors should be included in such decisions, as should ticket office managers who presumably have a thorough knowledge of ticket pricing and a pulse on industry trends. A college-based pricing team should also include marketers and financial managers, who will each bring their respective market-driven and cost-driven viewpoints to the discussion in an effort to identify potential problems and solutions to determine a workable compromise (Indounas, 2006). Lastly, due to the widespread compulsory nature of donations tied to season ticket purchases (Mahony et al., 2003), the development office should also bring important and unique insight to the pricing decision process. Based on the previous literature, we propose the following:

Proposition 2: Internal, supply-side stakeholders (athletic administrators) will each value the role of price differently based on their specific areas of expertise within the athletic department, thus leading to various sentiments regarding pricing initiatives.

Although they did not survey pricing managers, Rishe and Mondello (2003; 2004) contributed to the literature base of primary market pricing through their investigations of price determinants across teams and time. More specifically, they analyzed price differences between cities and teams to understand factors influencing pricing decisions for North American major sport leagues. The results indicated that playing in a new stadium, population size (except in the NFL), and qualifying for the playoffs the previous year all had significantly positive effects on price increases (Rishe \& Mondello, 2004).

Similar studies can be undertaken in the realm of intercollegiate athletics, and may yield different results given the unique factors specific to college sport. For instance, although such commonalities existed among professional sport leagues, it should not be assumed that athletic departments would increase ticket prices after a NCAA appearance in a particular sport, as administrators may opt to maintain prices in sports like volleyball and hockey, while increasing prices in sports such as football and baseball. Furthermore, as opposed to professional sport teams that primarily exist in large metropolitan areas, population size is a factor that may not necessarily influence pricing changes among NCAA Division I institutions, as schools exist in various locations across the United States that have wide variances in population (e.g., Starkville, MS population 23,888, home of Mississippi State University; Philadelphia, PA population 1.5 million, home of the University 
of Pennsylvania, Temple University, Drexel University, Villanova University, and Saint Joseph's University). Therefore, we propose the following:

Proposition 3: Although institutionalized mechanisms have been found to drive pricing strategy on the professional level, the factors affecting price in that environment will differ from those in the collegiate environment.

In a two-phase exploration of clubs in the English Premier League (EPL), Clowes and Clements (2003) examined the discriminatory pricing practices used throughout the league for both season ticket and single ticket purchases. Telephone interviews with team ticket officers were used to understand specific elements of pricing such as seat location, perceived quality of opponent, price banding, and price bundling. In terms of price discrimination practices, it was found that a central objective for most clubs was to increase the base of season-ticket holders, and each club offered third-degree price discrimination to financially restricted supporters such as juniors, retirees, and individuals with disabilities. Price bundling — grouping two or more single-game tickets into one package price — was found to be popular throughout the league, as was price banding - categorizing games by the perceived attractiveness of an opponent.

Pricing strategies and tactics should also be investigated to better understand the current ticketing landscape within college sports. As identified by Putler and Wolfe (1999), stakeholder identification is especially important in intercollegiate athletics. Given that administrators deal with a wide array of stakeholders unique to this setting, including alumni, faculty and staff, current students, potential students, and boosters, such an exploration of price discrimination practices would be particularly useful to better understand how these stakeholder groups might influence administrative pricing decisions. Furthermore, gaining a more comprehensive understanding of discriminatory pricing practices across NCAA-sponsored sports would also be useful in understanding the ways in which various athletic programs are viewed from a revenue standpoint by athletic administrators. Based on this literature the following proposition was developed:

Proposition 4: Various intercollegiate athletic stakeholder groups value tickets and influence price differently, thus leading athletic administrators to implement multiple segmentation and pricing strategies.

One of the most important takeaways from these studies of managerial pricing strategies is that there is no single blueprint for constructing a pricing policy in any spectator sport setting. However, Pitts and Stotlar (2013) use a marketing lens to suggest a type of strategic planning framework for effective pricing that encourages organizations to consider important contextual information for their unique situation when developing pricing policies. Specifically, they recommend acquiring relevant information from both consumers and the company itself, which acknowledges the importance of external and internal stakeholders, respectively. Furthermore, they recommend acquiring information from competitors and scanning the environment to assess the climate, each of which may influence the organization due to isomorphic pressure. Thus, acquiring information relative to an organization's consumers, company, competitors, and climate are necessary in initiating the pricing-decision process, as they each influence the setting of pricing objectives, which influences 
the selection of specific strategies and methods designed to meet those stated objectives, culminating in the determination of price (Pitts \& Stotlar, 2013).

Given that the pricing process described by Pitts and Stotlar (2013) is a generic model for both goods and services across the sport industry, an investigation of pricing processes used specifically in sport event ticketing is warranted. More specifically, the pricing processes used in the unique environment of intercollegiate athletics should be examined separately in an effort to differentiate between the pricing processes for season tickets as opposed to single-game tickets, including the influence of compulsory donations, as well as various consumer-, company-, competitor-, and climate-based factors, which can be guided by both stakeholder and institutional theories. Therefore, we propose the following:

Proposition 5: Stakeholder and institutional factors make the landscape of intercollegiate athletics distinct, therefore leading to pricing processes and policies that are unique to college-based ticketing compared to other segments of the sports industry.

\section{Primary Market Objectives}

Much of the existing literature on primary market ticketing comes from an economics perspective. More specifically, there has been discussion as to the objectives of sport teams, and those chosen objectives have implications that include pricing behavior (Kesenne \& Pauwels, 2006). However, as suggested by Drayer and Rascher (2013), "much of the research involving price by sports economists has been about how price impacts demand, not the related question of how to optimally set prices" (p. 124).

Profit Maximization. Economists consider both current and future profits, as well as both implicit (nonmonetary factors) and explicit (monetary factors) revenues and costs when determining profit maximization (Eschenfelder \& Li, 2007). Studies have suggested that NHL (Ferguson, Stewart, Jones, \& LeDressay, 1991) and MLB (Alexander, 2001) teams exhibit profit-maximizing behavior in regards to ticket pricing, leading economists to suggest that North American leagues are run as businesses, and thus operate in profit-maximizing capacities (Kesenne \& Pauwels, 2006; Madden, 2012). Meanwhile, Fort and Quirk (1999) have suggested that the big-business nature of intercollegiate athletics may be leading some athletic departments to exhibit profit-maximizing behavior as well.

In literature on the pricing strategies of teams exhibiting profit-maximizing behavior, authors suggest ticket prices tend to be set in the inelastic portion of the demand curve (Noll, 1974; Salant, 1992). Inelastic pricing describes a situation when consumer demand does not vary based on changes in price, indicating that when price increases there is a corresponding increase in revenue (Eschenfelder $\& \mathrm{Li}, 2007)$. Sport managers tend to only alter ticket prices in a manner that will have negligible effects on demand, due in part to the importance of ancillary revenues that can only be realized through on-site patronage (Fort, 2004; Coates \& Humphreys, 2007).

According to Fort (2004), pricing in the inelastic range of the demand curve is due, in part, to an organization's desire to solicit revenues from other areas of its operation such as parking and concessions. In short, by pricing tickets at levels 
that will consistently draw spectators into the venue, additional revenues are likely to be gained from the captive audience through purchases of food, beverage, and souvenirs, thus increasing the total revenues for the organization and ensuring maximum profits. Fort's postulation is supported by Krautmann and Berri (2007), who argue that profit-maximizing decision-makers might exhibit inelastic pricing behavior to increase concession sales, as well as Coates and Humphreys (2007), who found that inelastic ticket pricing is complemented by ancillary goods such as parking, concessions, and merchandise that are priced near the elastic portion of the demand curve.

Satisficing Behavior. Although organizations with profit-maximizing objectives may be solely concerned with increasing margins, it can be argued that it is impossible to know exactly what the highest achievable output will be. Given this ambiguous notion of maximum profits, owners and managers may instead aim to achieve acceptable, rather than optimal, goals (Eschenfelder \& Li, 2007). As suggested by Simon (1959), managers might set objectives for measurable items such as sales, growth, or profit. This satisficing model is thought to be a logical compromise to profit maximization (Salvatore, 2001). For example, rather than requiring marketers to develop a plan to "maximize revenues" for a particular game, administrators might instead give the marketing director the goal of selling out the game, which is a more concrete, measurable, and realistic mandate. This type of pricing objective was described by Drayer, Stotlar, and Irwin (2008) in a case study of one NFL team's pricing strategy, as the primary goal for the ticketing office was to sell out each game.

Also known as bounded rationality, another aspect of satisficing behavior theory is that managerial decisions may be constrained by both internal and external factors. Therefore, constraints such as time or insufficient information can lead managers to make satisficing decisions (Simon, 1945). As explained by Byers and Slack (2001), managers might rely on operational-decision making that is more focused on short-term solutions, rather than long-term strategic-decision making. Exhibiting such operational thought processes may in turn lead to satisficing pricing decisions that will adequately serve the organization in the short term, but does not necessarily reflect a strategy for developing committed, high value consumers with significant lifetime value (Stewart, Smith, \& Nicholson, 2003). Such behavior might also be explained via institutional theory, as uncertainty or ambiguity may lead firms to exhibit mimetic isomorphic traits by imitating actions of successful peers without regard for value congruity or long-term organizational health (DiMaggio \& Powell, 1983).

Fan Welfare Maximization. Boyd and Boyd (1998) suggest it should not be assumed that sport managers exhibit profit-maximizing behavior in ticket pricing. Another type of objective more commonly found among European soccer clubs is fan welfare maximization (FWM). In this setting "fans (or supporters) have a particular allegiance to a club, are the consumers of its products, and directly influence club policies" (Madden, 2012, p. 560). In organizations that are likely to use such an objective, the sport clubs (such as in the German Bundesliga) are membership organizations with elected officials determining strategy. This unique governance structure has been found to price tickets in the inelastic portion of the demand curve and draw larger crowds than profit-maximizers (Madden, 2012). 
FWM is congruent with the tenets of stakeholder theory, as both are focused on social rather than financial performance (Miles, 2012).

With these primary market objectives in mind, we argue that optimal pricing decisions cannot be made from a managerial perspective without first understanding the objectives of the sport entity. If intercollegiate athletic departments are, in fact, profit-maximizers as Fort and Quirk (1999) suggest, then the types of ancillary revenue streams that support such a claim should be investigated. More specifically, are ancillary goods such as concessions, souvenirs, and parking elastically priced at the college level as well? Furthermore, might there be additional ancillary revenue streams at play in college athletics that might not exist in professional sport? In addition, do schools tend to price tickets with a satisficing mindset, or are they more long-term strategic planners? Or, given the potential influence of alumni, boosters, and students, might it be that athletic departments are fan welfare maximizers? Based on these questions, we propose the following:

Proposition 6: The organizational objectives of intercollegiate athletic departments will vary, and such goal orientations will dictate the extent to which stakeholder groups and/or peer institutions influence ticket-pricing decisions.

\section{Secondary Market Research}

Historically, secondary ticket markets were limited to brokers and scalpers peddling product near the venue (Howard \& Crompton, 2004; Drayer, 2011). In recent years, however, there has been a shift toward web-based ticket resale platforms, allowing individuals to sell tickets in the relative safety of the online environment. Like many growth industries, this surge is due in large part to increased technological efficiencies afforded via the Internet and fewer legal restrictions on the practice of ticket resale (Drayer, 2011), which has led to the acceptance of online ticket market websites as part of a legitimate industry (Drayer, Shapiro, \& Lee, 2012).

Such web-based secondary markets provide opportunities for researchers to study pricing behavior in a demand-based environment unencumbered by selfimposed managerial constraints such as price floors and ceilings (Shapiro \& Drayer, 2012). Furthermore, Rishe (2014) suggests:

Secondary price research has become more prevalent in recent years as (1) variable and dynamic pricing became more common in sports, (2) online secondary pricing data became more readily accessible, and (3) both pricing managers for teams and online brokers became more willing to share their data (p. 68).

These reasons have allowed researchers to conduct investigations that have expanded our knowledge of pricing professional sport.

Until the late 2000s, ticket resale literature largely focused on the legalities of the industry (e.g., Happel \& Jennings, 1995). Since then, much of the secondary market research has centered on factors associated with price changes on the open market. Such real-time pricing variations are indicators of consumer demand, which can reflect significant differences from primary market prices. Sport studies utilizing secondary market data have found that factors such as team performance, population and income in the home team city, face value of ticket, day of the game, and days between the sale and game to be influential in the amount bidders were 
willing to offer for game tickets (Drayer \& Shapiro, 2009). In addition, research has found that fans are willing to pay premium prices for weekend games, key opponents, winning teams, and promotions (Paul \& Weinbach, 2013), and that prior and current season win percentages, rankings, ticket scarcity, new stadiums, and point spreads predict secondary market prices (Drayer, Rascher, \& McEvoy, 2012). Further research has supported that time-related factors have significant influence on secondary market pricing (Harrington \& Treber, 2014; Shapiro \& Drayer, 2012; Dwyer, Drayer, \& Shapiro, 2013).

As suggested above, there has been considerable secondary market research conducted on professional sports. However, only recently have researchers focused on intercollegiate events. For instance, Rishe (2014) and Rishe, Mondello, and Boyle (2014) have investigated secondary market transactions for the 2013 NCAA Men's NCAA Basketball Tournament, but those works were based on a postseason tournament in which prices are determined at the top governance-level (NCAA), thus excluding individual schools from the pricing process. Sanford and Scott (2014), however, have conducted secondary ticket market research that has more applicability for individual institutions by studying pricing efficiency for football season-ticket sales in the Southeastern Conference (SEC), finding that only three schools made market-value pricing decisions for high-quality seats.

Additional research should be conducted using secondary ticket-market data to better understand factors that affect purchase of sporting event tickets on the collegiate level from a demand-side, consumer behavior perspective. Furthermore, investigations using secondary market data can help to better inform athletic administrators concerning fan willingness-to-pay and, similar to the Sanford and Scott study, provide evidence of efficiencies for a number of pricing decisions such as price banding. Therefore, we propose the following:

Proposition 7: Both managerial price-setting and consumer ticket-purchasing behavior will differ between primary and secondary market stakeholder groups in the intercollegiate athletic environment.

\section{Conclusion}

The current landscape of sport pricing literature fails to distinguish between intercollegiate athletics and professional leagues, and although it has been suggested that college sport is increasingly commercialized, it is important to note that athletic departments are still divisions of nonprofit institutions of higher education (Pappano \& Tracy, 2009). While it could be argued that the distinction between college and professional sport in profit orientation alone is enough to justify the need to investigate their pricing practices separately, there are a number of other differences that we can point to as justification, including season-ticket purchase requirements, variance in college venue seating capacities, as well as cultures and traditions. But perhaps the most important distinction that can be drawn between college and professional sport is in organizational structure, where intercollegiate athletic departments are in a unique subsidiary relationship to the university. Operating in such a landscape can lead to accounting practices and managerial decision-making processes that are unique to college sport (McEvoy et al., 2013). As part of that unique structure, intercollegiate athletic departments 
are also under pressures, both internally and externally, that are not found in professional sport.

While pricing literature exists with regards to professional spectator sport in North America, the billion-dollar college sport industry has been left largely unexplored. However, as one of the most significant sources of generated revenue for athletic departments across the country, ticketing is a critical operational segment, and for those departments facing reduced financial support, ticket revenue is more vital than ever, thus providing further evidence that research focused on intercollegiate athletic ticket pricing is warranted. Although we can see anecdotal evidence that shows the implementation of various second-degree price discrimination methods in athletic departments across the country, we do not yet understand what goes into formulating pricing plans and making pricing decisions. Our understanding of intercollegiate athletic ticket pricing decisions can be extended, however, by studying the phenomenon through the lenses of both stakeholder theory and institutional theory.

Stakeholder theory is ripe for gaining necessary information on both external collegiate sport industry customers and the internal environment of the athletic department itself. Although myriad stakeholders have been identified in existing literature concerning college sport (Putler \& Wolfe, 1999), thorough consumer identification is an obvious first step in the process. Further research is needed to drill down to understand the motivations and behaviors of these various groups, including consumer responses to ticketing policy, as the factors important to demand-side stakeholders should be considered in the pricing process.

Although factors affecting attendance and ticket purchase for spectator sporting events have been well documented in the consumer behavior literature (e.g., Pan, Gabert, McGaugh, \& Branvold, 1997; Pan \& Baker, 2005), additional research is needed to more deeply understand the role that price plays in stakeholders' intent to purchase and the extent to which known consumer behavior factors impact managerial pricing decisions. Such information is key to understanding the "why" of both the consumer decision-making process to purchase tickets, and the administrative decision-making process to price tickets.

As generated revenue sources continue to grow in importance, the viability of self-sufficiency will rely upon athletic departments' ability to identify and manage the potentially disparate concerns of multiple stakeholders. In this sense, the context of college sport ticket pricing affords the opportunity to extend stakeholder theory by exploring various stakeholder categories to find (dis)similarities among the groups that may help inform pricing practices. Furthermore, from a supplyside view of stakeholder theory, research should investigate the degree to which athletic departments involve multiple athletic administrators in the pricing process to provide multiple viewpoints (Indounas, 2006).

Given the constraints that exist in intercollegiate athletics due to various levels of governance, and the relative youth of credible pricing strategies in intercollegiate athletics (Kirby, 2014), institutional theory is a logical framework from which to study this phenomenon as departments and universities seek legitimacy among their peers. Institutional theory may provide the theoretical grounding to investigate factors relating to the industry, environment, or other external elements beyond the department's control. Understanding the sources of influence and pressure can help explain the pricing decisions made by intercollegiate athletic administrators. 
Pitts and Stotlar (2013) warn against ignoring competitor prices and strategies, a sentiment reflected in research regarding the concept of WTP, as competitor pricing can influence consumer perception of value (Drayer \& Shapiro, 2011). More specifically, mimetic isomorphism has the potential to exist in college sport, especially as schools seek legitimacy, or if athletic departments are unsure how to establish their own price.

Furthermore, external factors that athletic administrators cannot control must be monitored (Pitts \& Stotlar, 2013), including coercive pressures such as laws, court decisions, NCAA or conference regulations, and the economy, which could all influence pricing policy. And finally, college sport ticket pricing is a unique context by which institutional theory can be extended by considering multiple layers of industry hierarchy where organizations may differ in historical relevance, resource availability, customer base, and popularity.

The overall lack of pricing research in the realm of intercollegiate athletics is disconcerting. Although hundreds of institutions charge admission for entry to watch intercollegiate athletic events, and despite the fact that those same schools generate millions in ticket sales revenue annually, there is a noticeable dearth in the literature regarding college-level ticketing. To gain meaningful insight into pricing practices on the collegiate level, the topic must be examined from a managerial perspective. This agenda provides a path for future exploration that can help to extend the literature on pricing and managerial operation in intercollegiate athletics.

\section{References}

Alexander, D.L. (2001). Major League Baseball: Monopoly pricing and profit-maximizing behavior. Journal of Sports Economics, 2(4), 341-355. doi:10.1177/152700250100200403

Bacon, J.U. (2015). Endzone: The rise, fall, and return of Michigan football. New York: St. Martin's Press.

Ben-Ner, A., \& Gui, B. (1993). The nonprofit sector in the mixed economy. Ann Arbor, MI: The University of Michigan Press.

Bowen, H.R. (1980). The costs of higher education: How much do colleges and universities spend per student and how much should be spend? San Francisco: Jossey-Bass.

Boyd, D.W., \& Boyd, L.A. (1998). The home field advantage: Implications for the pricing of tickets to professional team sporting events. Journal of Economics and Finance, 22(2-3), 169-179. doi:10.1007/BF02771486

Brayley, R.E., \& McLean, D.D. (2001). Managing financial resources in sport and leisure service organizations. Champaign, IL: Sagamore.

Byers, T., \& Slack, T. (2001). Strategic decision-making in small businesses within the leisure industry. Journal of Leisure Research, 33(2), 121-136.

Charlotte Sports Information. (2015). Football media guide. Charlotte, NC: Charlotte Athletics.

Chelladurai, P., \& Danylchuk, K.E. (1984). Operative goals of intercollegiate athletics: Perceptions of athletic administrators. Canadian Journal of Applied Sport Sciences, 9(1), 33-41. PubMed

Clotfelter, C.T. (2011). Big-time sports in American universities. New York: Cambridge University Press. doi:10.1017/CBO9780511976902

Clowes, J., \& Clements, N. (2003). An exploration of discriminatory ticket pricing practice in the English football Premier League. Managing Leisure, 8(3), 105-120. doi:10.1080/1360671032000123645 
Coates, D., \& Humphreys, B.R. (2007). Ticket prices, concessions and attendance at professional sporting events. International Journal of Sport Finance, 2, 161-170.

Covell, D. (2004). Attachment, allegiance and a convergent application of stakeholder theory to Ivy League athletics. International Sports Journal, 8(1), 14-26.

Covell, D. (2005). Attachment, allegiance and a convergent application of stakeholder theory: Assessing the impact of winning on athletic donations in the Ivy League. Sport Marketing Quarterly, 14(3), 168-176.

Cunningham, G.B. (2009). Understanding the diversity-related change process: A field study. Journal of Sport Management, 23(4), 407-428. doi:10.1123/jsm.23.4.407

Cunningham, G.B., \& Ashley, F.B. (2001). Isomorphism in NCAA athletic departments: The use of competing theories and advancement of theory. Sport Management Review, 4, 47-63. doi:10.1016/S1441-3523(01)70069-1

Danylchuk, K.E., \& Chelladurai, P. (1999). The nature of managerial work in Canadian intercollegiate athletics. Journal of Sport Management, 13, 148-166. doi:10.1123/ jsm.13.2.148

DiMaggio, P.J., \& Powell, W.W. (1983). The iron cage revisited: Institutional isomorphism and collective rationality in organizational fields. American Sociological Review, 48, 147-160. doi:10.2307/2095101

Drayer, J. (2011). Making a case for the integration of the primary and secondary ticket markets for professional team sports in the United States. International Journal of Sports Marketing \& Sponsorship, 12(3), 199-208. doi:10.1108/IJSMS-12-03-2011-B002

Drayer, J., \& Rascher, D.A. (2013). Sport pricing research: Past, present, and future. Sport Marketing Quarterly, 22(3), 123-128.

Drayer, J., \& Shapiro, S.L. (2009). Value determination in the secondary ticket market: A quantitative analysis of the NFL playoffs. Sport Marketing Quarterly, 18(1), 5-13.

Drayer, J., \& Shapiro, S.L. (2011). An examination into the factors that influence consumers' perceptions of value. Sport Management Review, 14, 389-398. doi:10.1016/j. smr.2010.11.001

Drayer, J., Rascher, D.A., \& McEvoy, C.D. (2012). An examination of underlying consumer demand and sport pricing using secondary market data. Sport Management Review, 15(4), 448-460. doi:10.1016/j.smr.2012.03.005

Drayer, J., Shapiro, S.L., \& Lee, S. (2012). Dynamic ticket pricing in sport: An agenda for research and practice. Sport Marketing Quarterly, 21(3), 184-194.

Drayer, J., Stotlar, D.K., \& Irwin, R.L. (2008). Tradition vs. trend: A case study of team response to the secondary ticket market. Sport Marketing Quarterly, 17(4), 184-194.

Dwyer, B., Drayer, J., \& Shapiro, S.L. (2013). Proceed to checkout? The impact of time in advanced ticket purchase decisions. Sport Marketing Quarterly, 22(3), 166-180.

Eschenfelder, M.J., \& Li, M. (2007). Economics of Sport (2nd ed.). Morgantown, WV: Fitness Information Technology.

Ferguson, D.G., Stewart, K.G., Jones, J.C.H., \& LeDressay, A. (1991). The pricing of sports events: Do teams maximize profits? The Journal of Industrial Economics, 39(3), 297-310. doi: $10.2307 / 2098521$

Fort, R. (2004). Inelastic sports pricing. Managerial and Decision Economics, 25, 87-94. doi:10.1002/mde.1108

Fort, R., \& Quirk, J. (1999). The college football industry. In J. Fizel, E. Gustafson, \& L. Hadley (Eds.), Sports economics: Current research (11-25). Westport, CT: Praeger.

Freeman, R.E. (1984). Strategic management: A stakeholder approach. Boston, MA: Pitman. Fulks, D.L. (2015). Revenues \& Expenses: 2004-2014 NCAA Division I Intercollegiate Athletics Programs Report. Indianapolis, IN: National Collegiate Athletic Association.

Happel, S., \& Jennings, M. (1995). The folly of anti-scalping laws. The Cato Journal, 15, 65-80. Harrington, D.E., \& Treber, J. (2014). Does it pay to wait? The paths of posted prices and ticket composition for the Final Four and Super Bowl. Journal of Sports Economics, 15(4), 559-576. doi:10.1177/1527002514535172 
Hester, P.T., Bradley, J.M., \& Adams, K.M. (2012). Stakeholders in systems problems. International Journal of System of Systems Engineering, 3(3/4), 225-232. doi:10.1504/ IJSSE.2012.052687

Howard, D.R., \& Crompton, J.L. (2004). Tactics used by sports organizations in the United States to increase ticket sales. Managing Leisure, 9, 87-95. doi:10.1080/13606710 410001709617

Huck, S., Kirchsteiger, G., \& Oechssler, J. (2005). Learning to like what you have: Explaining the endowment effect. Economic Journal (Oxford), 115(7), 689-702. doi:10.1111/j.1468-0297.2005.01015.x

Humphreys, B.R. (2006). The relationship between big-time college football and state appropriations of higher education. International Journal of Sport Finance, 1, 119-128.

Hums, M.A., \& MacLean, J.C. (2013). Governance and policy in sport organizations (3rd ed.). Scottsdale, AZ: Holcomb Hathaway.

Indounas, K. (2006). Making effective pricing decisions. Business Horizons, 49, 415-424. doi:10.1016/j.bushor.2006.02.003

Jones, T.M., \& Wicks, A.C. (1999). Convergent stakeholder theory. Academy of Management Review, 24(2), 206-221.

Kelly, D., \& Dixon, M.A. (2011). Becoming a "real university:" The strategic benefits of adding football for NCAA Division I institutions. Journal of Intercollegiate Sport, 4(2), 283-303. doi:10.1123/jis.4.2.283

Kesenne, S., \& Pauwels, W. (2006). Club objectives and ticket pricing in professional team sports. Eastern Economic Journal, 32(3), 549-560.

Kim, Y.K., \& Trail, G. (2010). Constraints and motivators: A new model to explain sport consumer behavior. Journal of Sport Management, 24(2), 190-210. doi:10.1123/ jsm.24.2.190

Kirby, T. (2014). Fighting sports revenue erosion. Sacramento, CA: Kirby Publishing.

Kotler, P. (1991). Marketing management: Analysis, planning, implementation and control (7th ed.). Englewood Cliffs, NJ: Prentice Hall.

Krautmann, A.C., \& Berri, D.J. (2007). Can we find it at the concessions? Understanding price elasticity in professional sports. Journal of Sports Economics, 8(2), 183-191. doi:10.1177/1527002505275093

Kretovics, M.A. (2011). Business practices in higher education: A guide for today's administrators. New York: Routledge.

Madden, P. (2012). Fan welfare maximization as a club objectives in a professional sports league. European Economic Review, 56, 560-578. doi:10.1016/j.euroecorev.2011.12.006

Mahony, D.F., Gladden, J.M., \& Funk, D.C. (2003). Examining athletic donors at NCAA Division I institutions. International Sports Journal, 7(1), 9-27.

Matheson, V.A., O’Connor, D.J., \& Herberger, J.H. (2012). The bottom line: Accounting for revenues and expenditures in intercollegiate athletics. International Journal of Sport Finance, 7(1), 30-45.

McEvoy, C.D., Morse, A.L., \& Shapiro, S.L. (2013). Factors influencing collegiate athletic department revenues. Journal of Issues in Intercollegiate Athletics, 6, 249-267.

Michigan Athletic Communications. (2015). Football media guide. Ann Arbor, MI: Michigan Athletics.

Miles, J.A. (2012). Management and organization theory. San Francisco, CA: Jossey-Bass.

Mitchell, R.K., Agle, B.R., \& Wood, D.J. (1997). Toward a theory of stakeholder identification and salience: Defining the principle of who and what really counts. Academy of Management Review, 22(4), 853-886.

Noll, R. (1974). Attendance and price setting. In R. Noll (Ed.), Government and the Sport Business (pp. 115-157). Washington, DC: Brookings Institute.

O'Hallarn, B., Morehead, C.A., \& Pribesh, S. (2016). Gaining S-T-E-A-M: A general athletic department social media strategy. Journal of Issues in Intercollegiate Athletics, 9, 39-61. 
Pan, D.W., \& Baker, J.A. (2005). Factors, differential market effects, and marketing strategies in the renewal of season tickets for intercollegiate football games. Journal of Sport Behavior, 28(4), 351-377.

Pan, D.W., Gabert, T.E., McGaugh, E.C., \& Branvold, S.E. (1997). Factors and differential demographic effects on purchases of season tickets for intercollegiate basketball games. Journal of Sport Behavior, 20(4), 447-463.

Pappano, L., \& Tracy, A.J. (2009). Ticket office sexism: The gender gap in pricing for NCAA Division I basketball. Wellesley Centers for Women Working Paper Series, 432. Wellesley, MA: Wellesley Centers for Women

Paul, R.J., \& Weinbach, A.P. (2013). Determinants of dynamic pricing premiums in Major League Baseball. Sport Marketing Quarterly, 22(3), 152-165.

Pitts, B.G., \& Stotlar, D.K. (2013). Fundamentals of Sport Marketing (4th ed.). Morgantown, WV: Fitness Information Technology.

Putler, D.S., \& Wolfe, R.A. (1999). Perceptions of intercollegiate athletic programs: Priorities and tradeoffs. Sociology of Sport Journal, 16(4), 301-325. doi:10.1123/ssj.16.4.301

Rascher, D., \& Schwarz, A. (2010). Illustrations of price discrimination in baseball. Germany: University Library of Munich., Retrieved from https://mpra.ub.uni-muenchen. de/25807/1/MPRA_paper_25807.pdf.

Reese, J.T., \& Mittelstaedt, R.D. (2001). An exploratory study of the criteria used to establish NFL ticket prices. Sport Marketing Quarterly, 10(4), 223-230.

Ridpath, D.B., Porto, B., Gurney, G., Lopiano, D., Sack, A., Willingham, M., \& Zimbalist, A. (2015, March 2). Position statement: Student feel allocations to fund intercollegiate athletics. The Drake Group. Retrieved from https://drakegroupblog.files.wordpress. com/2015/04/position-statement-student-fees-final-3-2-15.pdf

Rishe, P. (2014). Pricing insanity at March Madness: Exploring the causes of secondary price markups at the 2013 Final Four. The International Journal of Sport and Society, 4, 67-73.

Rishe, P., \& Mondello, M. (2004). Ticket price determination in professional sports: An empirical analysis of the NBA, NFL, NHL, and Major League Baseball. Sport Marketing Quarterly, 13(2), 104-112.

Rishe, P.J., \& Mondello, M.J. (2003). Ticket price determination in the National Football League: A quantitative approach. Sport Marketing Quarterly, 12(2), 72-79.

Rishe, P.J., Mondello, M., \& Boyle, B. (2014). How event significance, team quality, and school proximity affect secondary market behavior at March Madness. Sport Marketing Quarterly, 23(4), 212-224.

Sack, A.L. (1987). College sport and the student-athlete. Journal of Sport and Social Issues, 11(1-2), 31-48. doi:10.1177/019372358701100103

Salant, D.J. (1992). Price setting in professional team sports. In D.J. Sommers (Ed.), Diamonds are forever, the business of baseball. Washington, DC: The Brookings Institute.

Salvatore, D. (2001). Managerial economics in a global economy (4th ed.). New York: McGraw-Hill.

Sanford, K., \& Scott, F. (2014). What are SEC football tickets worth? Evidence from secondary market transactions. Southern Economic Journal, 81(1), 23-55. doi:10.4284/00384038-2011.051

Schrecker, E. (2010). The lost soul of higher education: Corporatization, the assault on academic freedom, and the end of the American university. New York: The New Press.

Shapiro, S.L., \& Drayer, J. (2012). A new age of demand-based pricing: An examination of dynamic ticket pricing and secondary market prices in Major League Baseball. Journal of Sport Management, 26(6), 532-546. doi:10.1123/jsm.26.6.532

Simon, H.A. (1945). Administrative behavior. New York: Free Press.

Simon, H.A. (1959). Theories of decision-making in economics and behavioral science. The American Economic Review, 49(3), 253-283. 
Smith, J., \& Washington, M. (2014). Advancing isomorphism in higher education: A critical analysis of the careers of intercollegiate athletic directors. Journal of Contemporary Athletics, 8(1), 15-35.

Smith, M. (2015a, August 24). Moving tickets on campus. Sports Business Journal, 18(19), $1 ; 17-23 ; 27$.

Smith, M. (2015b). Some hoops programs buck attendance trend. Sports Business Journal, 17(44), 8 .

Stewart, B., Smith, A.C.T., \& Nicholson, M. (2003). Sport consumer typologies: A critical review. Sport Marketing Quarterly, 12(4), 206-216.

Ward, R.E. (2015). Buried accomplishments: Institutional isomorphism in college athletics mission statements. International Journal of Sport Communication, 8, 18-45. doi:10.1123/IJSC.2014-0018

Weisbrod, B.A., Ballou, J.P., \& Asch, E.D. (2008). Mission and money: Understanding the university. New York: Cambridge University Press.

Welty Peachey, J., \& Bruening, J. (2011). An examination of environmental forces driving change and stakeholder responses in a Football Championship Subdivision athletic department. Sport Management Review, 14, 202-219. doi:10.1016/j.smr.2010.09.002 